\title{
DA MATEMÁTICA PARA O PORTUGUÊS
}

Patricia Queiroga Gonçalves de Souza Reis* Maria Cecilia de Magalhães Mollica** Marisa Beatriz Bezerra Leal ${ }^{* * *}$ Maria de Fátima Bacelar da Silva ${ }^{* * * *}$

\begin{abstract}
Resumo: Na área de Educação, no que se refere à aplicação de conteúdos escolares, principalmente nos anos iniciais do Ensino Fundamental, tem-se buscado, segundo Mollica \& Leal (2009), metodologia pedagógica que trabalhe conjuntamente com as disciplinas Português e Matemática. Na prática, percebe-se que o professor parte primeiramente dos conteúdos do Português para depois inserir conhecimentos matemáticos. O presente trabalho verifica como é possível percorrer o caminho inverso: chegar às habilidades da lectoescritura a partir da Matemática. Em parceria com a Faculdade de Letras e o Instituto de Matemática, ambas Unidades da UFRJ , a pesquisa enfocou turmas do Projeto de Letramento de Jovens e Adultos - COPPE, vinculado à CODEP da Pró Reitoria de Pessoal - PR4, que teve início em 2005 e, até o presente momento, já encaminhou mais de $90 \%$ dos alunos para o ensino regular, mantendo permanente contato com seus egressos. No estudo, foram aplicadas atividades lúdicas de Matemática e Português, iniciando-se de conteúdos da Matemática. Todas as propostas pedagógicas valorizaram a oralidade e as experiências de vida dos educandos - letramento social, sem se descuidar do caráter formativo pertinente ao letramento escolar.
\end{abstract}

Palavras-chave: Educação de Jovens e Adultos, Interdisciplinariedade, propostas pedagógicas.

\section{Introdução}

A interdisciplinaridade vem sendo bastante ressaltada atualmente. Questiona-se cada vez mais a respeito do hibridismo teórico-metodológico e o fim do ideal de neutralidade e objetividade em relação à produção de conhecimentos. Moita Lopes (2004) discute os limites das disciplinas ao ponderar que, na contemporaneidade, é essencial a troca de informações e as contribuições que uma área pode trazer para a outra.

Assim, os limites entre as disciplinas devem ser apagados sempre que possível numa estreita interação. Pesquisas que atravessem várias áreas de investigação têm sido bastante valorizadas nos eventos científicos interdisciplinares, o que causa bastante estranhamento àqueles que seguem paradigmas tradicionais e se mantêm dentro dos limites disciplinares. A dificuldade de diálogo dos pesquisadores nas Instituições é supostamente responsável pela manutenção de orientação antiga, pois “a diferença interroga, assusta e questiona nossas verdades.” (Moita Lopes, 2004: 72.). A

\footnotetext{
*Aluna de Graduação em Letras da UFRJ e professora-bolsista do Projeto de Letramento de Jovens e Adultos COPPE / CODEP

${ }_{* * *}^{* *}$ Doutora em Linguística, CNpq e professora titular do departamento de Linguística da UFRJ

*** Doutora em Matemática e professora do Instituto de Matemática da UFRJ

**** Graduada em Pedagogia com especialização em magistério e orientação educacional pela ABEU e professora do Projeto de Letramento de Jovens e Adultos COPPE / CODEP - UFRJ
} 
capacidade de reinvenção é crucial no mundo da pesquisa, uma vez que as verdades científicas são possibilidades de tratar certas questões, são efêmeras.

Seguindo o viés contemporâneo, desenvolvemos um trabalho em parceria com a Faculdade de Letras e o Instituto de Matemática da UFRJ. Tendo em vista propostas pedagógicas que incentivem o trabalho interdisciplinar entre o Português e a Matemática na Educação de Jovens e Adultos, mostramos resultados satisfatórios partindo da aplicação de conteúdos que exigem habilidades matemáticas, seguindo-se aos de Português, situação inversa à prática em que frequentemente os conhecimentos matemáticos são explorados a partir de atividades de linguagem.

\section{Considerações teóricas}

Este trabalho, então, pauta-se na defesa de uma reformulação na prática de ensino (Mollica, 2007; Antunes, 2003; Bortoni-Ricardo, 2004), ao valorizar uma ação pedagógica que desconstrói o paradigma de educação enciclopédica, enlatada. Enfatiza Irandé Antunes (2003) que cabe ao professor criar, pesquisar, observar, levantar hipóteses, analisar, aprender, reaprender e desprenderse dos livros didáticos. Os conteúdos têm que ser planejados em vários espaços e formas de pensamento; deve haver criação de possibilidades com pesquisa, curiosidade, crítica, reflexão. Nesse quadro, o educador se dispõe a aprender e a construir junto com o aluno. $\mathrm{O}$ sociointeracionismo no ensino-aprendizado (Vigotsky, 1987) apregoa que são igualmente construtores de significados professor e alunos. Aquele, consciente de sua prática pedagógica, procura tornar todos colaboradores e participantes; estes, por vez, tornam-se co-autores do seu aprendizado.

No âmbito da Educação de Jovens e Adultos e de acordo com Paulo Freire, há de se considerar alguns aspectos fundamentais que definem os alunos de EJA. Segundo Oliveira (1999), é importante levar em conta a peculiaridade dos alunos quanto à (I) condição de não crianças, (II) condição de excluídos da escola, (III) condição de membros de determinados grupos culturais. Acrescentam ainda Mollica \& Leal (2008: 99):

Além desses elementos, o alfabetizador deve entender o $3^{\circ}$ turno naturalmente e não como
aquele em que realizamos o último trabalho da escola com alunos que estão tendo uma
última oportunidade. Assim, as atividades com alfabetizadores jovens e adultos deverão ser
incorporadas a uma ação educativa interdisciplinar, destinada a um público marcado pela
exclusão, que retorna aos bancos escolares com uma riqueza de conhecimentos matemáticos
e de linguagem. Há que se valorizar os conhecimentos prévios e dar acesso à forma-
conteúdo escolar, com o entendimento mais ampliado de um processo maior que envolve o
letramento social e escolar.

Ressaltam as autoras a indissociabilidade entre a linguagem matemática e a língua materna. A primeira dependente de uma perfeita articulação com o ensino da segunda: 
Segundo Machado (2001), quando se observam os elementos dos dois sistemas fundamentais para a representação da realidade, o alfabeto e os números, descobre-se que eles são aprendidos conjuntamente pelos indivíduos antes mesmo de os educandos chegarem à escola. A matemática tem uma linguagem exclusivamente escrita, entendendo-se aqui, a alfabetização como o processo de aquisição do código escrito, no qual estão inseridos os escritos matemáticos e a codificação verbal escrita, cujos processos de leitura e escrita ultrapassam o nível de mero reconhecimento e representação de letras e números. (Mollica \& Leal, 2008: 101)

Feitas as devidas considerações, cabe lembrar a importância de propostas pedagógicas que levem em conta o conhecimento que o aprendiz já traz e que deve ser aproveitado no processo de ensino. Segundo Paulo Freire (1987) não se deve excluir o educando de sua cultura, tampouco torná-lo um mero depositário da cultura dominante. É preciso valorizar a pedagogia que privilegia o conhecimento de mundo do aluno e que não separa os conteúdos dos dois campos de conhecimento conforme advogam Mollica \& Leal (2006).

Nessa direção, com o objetivo de trabalhar os conteúdos de Português e de Matemática, propusemos desenvolver em sala de aula situações que fazem parte do cotidiano dos educandos, aproveitando-lhes as experiências de vida e os conhecimentos de mundo. Escolhemos como pano de fundo o supermercado, pois a ida às compras nesse contexto constitui um ato automatizado na vida das pessoas: os resultados obtidos por Mollica \& Leal (2009) apontaram na direção de que os indivíduos, nessa etapa de escolarização, adquirem os produtos sem conhecer a forma de usá-los e sem se preocupar com as informações contidas nos rótulos.

\section{Metodologia}

A pesquisa contou com a observação-participativa das pesquisadoras, dados colhidos em notas de campo, gravações em áudio, fotografias das atividades e entrevistas. O contexto estudado foi a sala de aula de Ensino Fundamental do Projeto de Letramento de Jovens e Adultos COPPE/CODEP- PR4 que tem como objetivo promover o acesso de jovens e adultos à escolaridade básica, em especial os servidores e funcionários da COPPE - UFRJ e seu entorno. Contamos com a participação de 12 alunos, sendo 4 homens e 8 mulheres. A faixa etária variou entre 38 e 71 anos. Foram desenvolvidas propostas pedagógicas, que abarcam conhecimentos das duas disciplinas Português e Matemática, distribuídas em 4 etapas. Em todas elas partiu-se primeiramente dos conteúdos da Matemática para posteriormente aplicar os de Português - situação contrária à prática habitual. A seguir, expomos a atividade passo a passo, ressaltando os objetivos de cada tarefa proposta.

\section{Aplicação da atividade:}

Durante uma das atividades, os alunos são os funcionários do supermercado. Cada dupla (ou grupo) de alunos é responsável por uma sessão e deve cumprir as tarefas que o professor (gerente) 
estabelecer. A divisão do trabalho em etapas facilita a aplicação pedagógica, conforme verificado a seguir:

\section{$1^{\text {a }}$ etapa}

Todas as mercadorias encontram-se fora das prateleiras e os alunos devem seguir os seguintes passos:

a- Observar os produtos que estão com a validade vencida e separar os demais em uma cesta. Para isso, recorrer a um calendário como material de apoio.

b- As mercadorias que estão dentro do prazo de validade devem ser organizadas no sentido da esquerda para a direita utilizando a ordem crescente de tamanho.

c- Produtos iguais devem ser dispostos em fileiras e em ordem decrescente de validade para que, os que estiverem com a validade prestes a vencer, sejam logo consumidos

Nessa etapa, trabalhamos variados conteúdos de Matemática que exigiam habilidades diferenciadas: as funções dos números (ordenação, quantificação e codificação), lateralidade, organização de espaço, formas geométricas, unidade de volume e proporcionalidade. Todos os conteúdos surgiram naturalmente, através de observações feitas a partir do manuseio dos produtos e a vivência dos alunos participantes. Os conceitos foram explorados e sistematizados somente através da oralidade. Os cálculos processados ao longo da atividade foram discutidos oralmente pelos alunos, por vezes com a mediação da professora.

\section{$2^{\mathbf{a}}$ etapa}

Os produtos com prazos de validade vencidos, que foram separados numa cesta no início da primeira etapa, devem ser relacionados em uma tabela para "baixa no estoque" e devolvidos ao fabricante. A tabela contém duas colunas. Na primeira, sugere-se que sejam anotados os nomes dos produtos e, na segunda, a data do vencimento, sempre em ordem alfabética. Dessa forma, ingressa$\wedge$ L`\} data de vencimento. Embora não se possa separar a Matemática da Língua Materna, já que a Matemática não tem oralidade própria, em nenhum momento do estágio anterior, foram solicitadas aos alunos a leitura e a escrita do nome dos produtos selecionados: a leitura ocorreu espontaneamente em alguns casos e, em outros, o ícone da marca dos itens conhecidos pelos alunos permitiu a identificação sem que a decodificação dos códigos ortográficos fosse realizada. Importante ressaltar que todos realizaram a leitura dos números na etapa anterior, mesmo quando a compreensão leitora não foi alcançada: por exemplo, não identificaram que, numa data representada no formato d/m/a, o número do meio representava o mês do ano. 


\section{$3^{\mathrm{a}}$ etapa}

Alguns produtos entraram na promoção e tiveram uma redução de R\$ 0,52 (sugestivo). Esses itens foram identificados com uma etiqueta que deveria registrar o preço promocional e ser relacionados em uma tabela com nome, preço normal e preço promocional. O objetivo consiste em exercitar as operações de adição e subtração, bem como a leitura e a escrita do nome dos produtos.

Abaixo, a sugestão para a tabela:

\section{Tabela de reajuste de preços}

Os itens abaixo entraram na promoção e tiveram uma redução de preço de $\mathrm{R} \$ 0,52$. Complete o nome dos produtos e faça o reajuste dos preços na tabela:

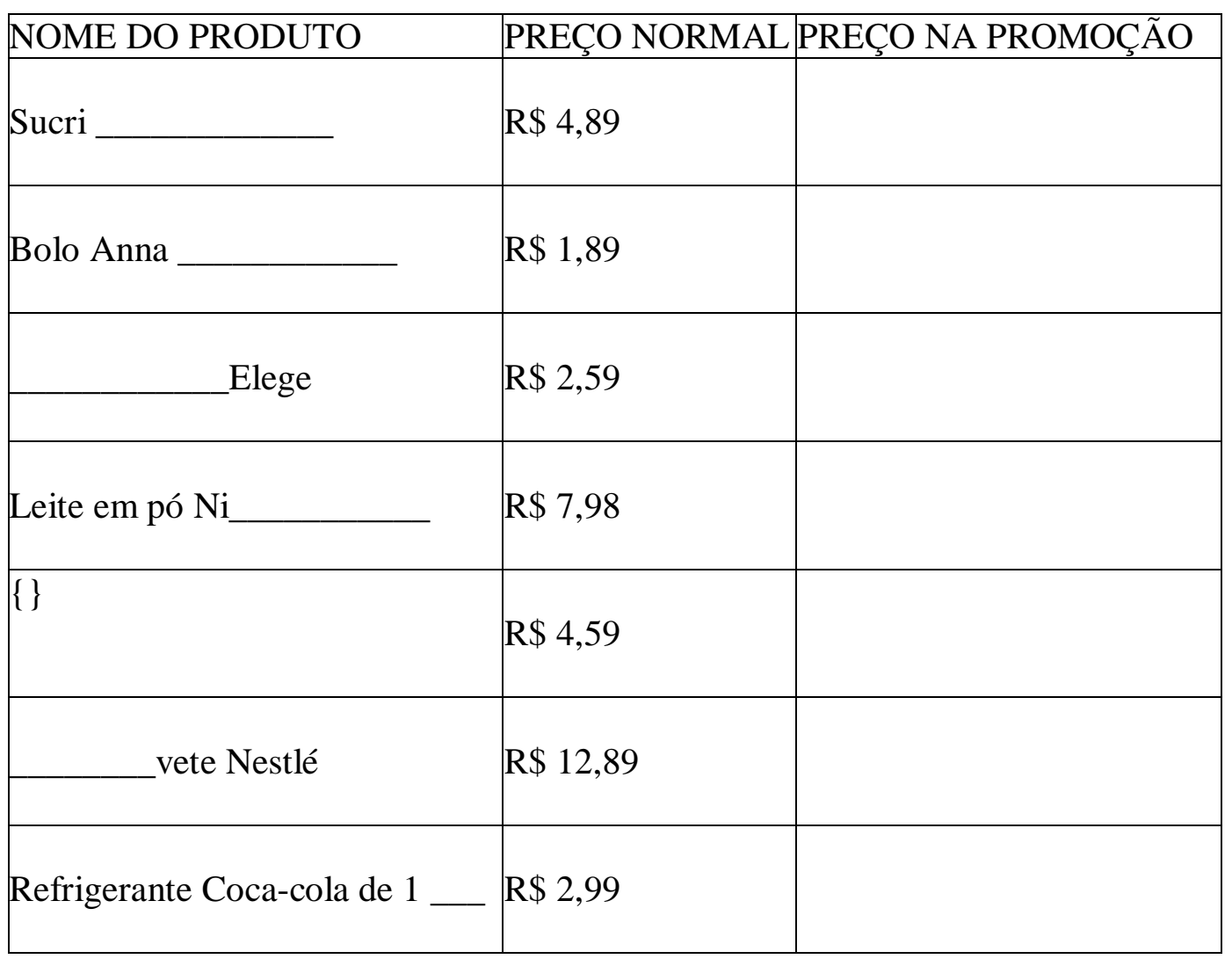

Nessa etapa, novamente a interdisciplinaridade esteve presente. Além de preencher a tabela com o valor obtido após a realização das operações onde o registro coletivo foi incentivado, os alunos também trabalharam os conceitos de dígrafo, hiato e encontros consonantais.

\section{$4^{\mathrm{a}}$ etapa}

Fazer um exercício de cruzadinha com palavras e conceitos explorados anteriormente que apresentam, normalmente, um certo grau de dificuldade, seja pela arbitrariedade na escrita, seja pelo processo de transferência fonético-fonológica da fala para a escrita. A finalidade é a de induzir o aluno à escrita da palavra segundo a norma culta, uma vez que a cruzadinha apresenta o número exato de letras que a palavra possui. Observe: 


\section{Exercício de cruzadinhas}

\begin{tabular}{|c|c|}
\hline 1- É um dos ingredientes do strogonoff. & $\begin{array}{l}\text { 8- Ajuda a dar um cheiro bom ao } \\
\text { banheiro. }\end{array}$ \\
\hline 2- Usamos para lavar roupas. & $\begin{array}{l}\text { 9- A mulher usa no seu período } \\
\text { menstrual. }\end{array}$ \\
\hline $\begin{array}{l}\text { 3- É o companheiro do feijão no prato } \\
\text { brasileiro. }\end{array}$ & 10- Para fazer mingau precisamos de \\
\hline 4- Usamos para lavar os cabelos. & 11- É usado para lavar louça. \\
\hline 5- No churrasco temos arroz com & 12- O brasileiro gosta de pão com \\
\hline 6- No rodízio de massas temos a & 13- É usado para fazer feijoada. \\
\hline 7- Quando acordamos tomamos café com & \\
\hline
\end{tabular}

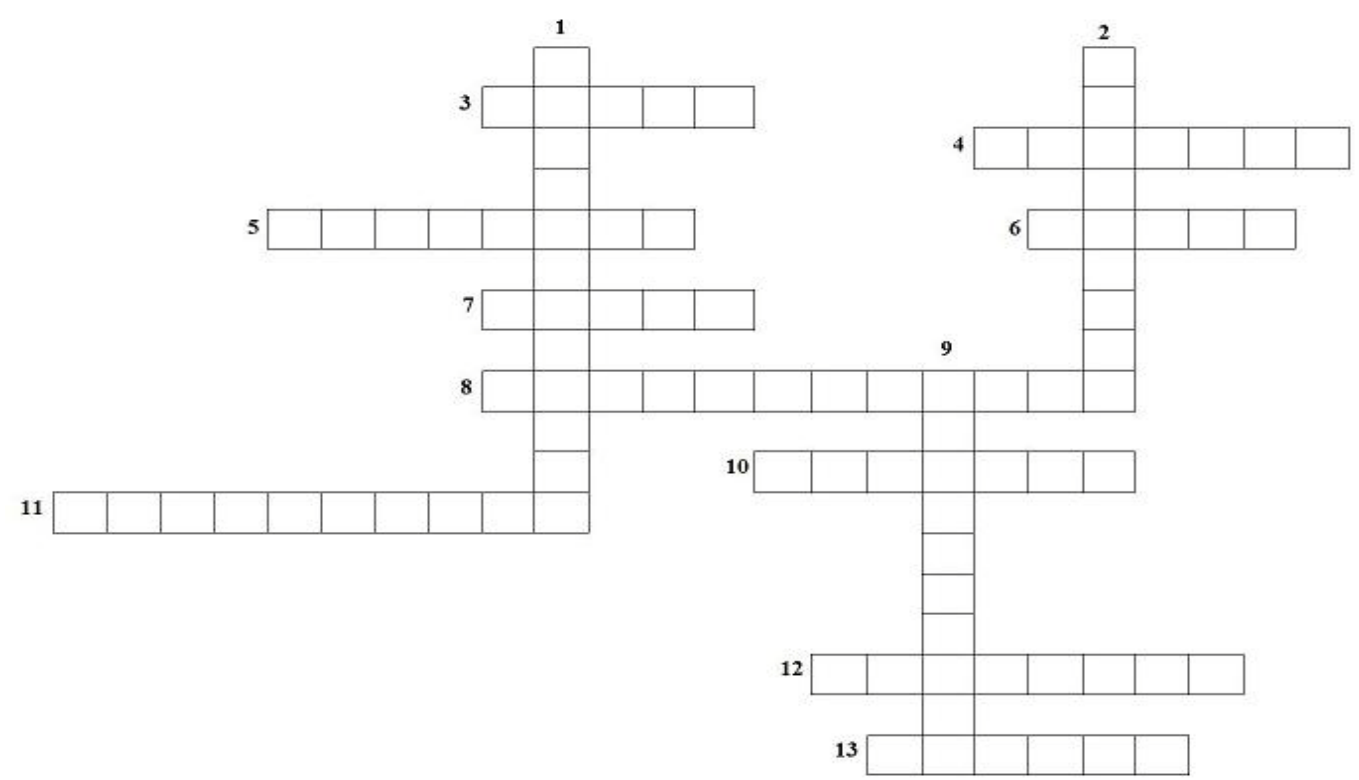

Embora a proposta tenha como meta principal a leitura e a escrita na língua materna, a matemática esteve presentes pois pressupõe-se a contagem das letras das palavras.

\section{Considerações finais}

No âmbito da interdisciplinaridade, foi possível ratificar que, no processo de ensinoaprendizado, especialmente em EJA, pouco importa a escolha da disciplina para iniciar-se uma atividade pedagógica. Especificamente neste texto, comprovamos a viabilidade de proposta direcionada que atenda às duas áreas de conhecimento iniciando-se pelos conteúdos matemáticos. 
A primeira etapa contemplou a oralidade, ora em voga, mas desprestigiada no ensino de Matemática. Motivados, os alunos perceberam a necessidade de registrar o que havia sido anteriormente discutido e o processo da fala para escrita evoluiu de forma natural. Foi possível perceber também que os alunos não “separaram” as atividades de Matemática das de Português. Os conteúdos integraram-se de tal forma, que a turma passou a indicar caminhos com diferentes conteúdos de áreas diversas sem que fosse necessária a existência de uma ordenação prévia. A integração das disciplinas facilitou a transposição dos conhecimentos advindos do letramento social para o letramento escolar.

Ressalta-se, antemão, inestimável relevância social neste tipo de atividade, uma vez que, baseada numa situação cotidiana, supõe-se o compartilhamento dos conhecimentos adquiridos por parte do alunos com seus pares e familiares.

\section{Referências}

ANTUNES, I. Aula de português: encontro \& interação. São Paulo: Parábola Editorial, 2003.

BORTONI-RICARDO, S M. Educação em língua materna: a sociolinguística na sala de aula. São Paulo: Parábola Editorial, 2004.

FREIRE, P. Pedagogia do Oprimido. 17ed. Rio de Janeiro: Paz e Terra, 1987.

MACHADO, N J. Matemática e língua materna: análise de uma impregnação mútua. São Paulo: Cortez, 2001.

MOLLICA, M C. Fala, letramento e inclusão social. 2ed. Rio de Janeiro: Contexto, 2007.

MOLLICA, M C \& LEAL, M. A Matemática e o Português na Alfabetização de Jovens e Adultos. Rio de Janeiro: Revista Revej@, 2008. . Letramento em EJA. Rio de Janeiro: Parábola Editoral, 2009.

MOITA LOPES, L P. Contemporaneidade e construção do conhecimento na área de Estudos Lingüísticos. Minas Gerais: Revista Scripta, 2004.

OLIVEIRA, M K. de. Jovens e Adultos como sujeitos de conhecimento e aprendizagem. São Paulo: Revista Brasileira de Educação- ANPED, 1999.

SOARES, M. Letramento e Escolarização. In: RIBEIRO, V. M. (org.) Letramento no Brasil. São Paulo: Global Editora, 2003.

VYGOTSKY, L. S. A Formação Social da Mente. São Paulo: Martins Fontes, 1987.

Parte desse trabalho foi apresentado na Jornada de Iniciação Científica e Cultural da UFRJ no Instituto de Matemática e contou com a participação Taísa Guindini Gonçalves e Karine Oliveira Bastos alunas de graduação, respectivamente, do Instituto de Matemática e da Faculdade de Letras. 


\title{
A FORÇA ARGUMENTATIVA DOS NEOLOGISMOS: ESTRATÉGIAS DISCURSIVAS EM CRÔNICAS DE ARNALDO JABOR
}

Shirley Lima da Silva Braz* André Crim Valente ${ }^{* *}$

\begin{abstract}
Resumo: Este artigo visa à análise de neologismos lexicais em algumas crônicas de Arnaldo Jabor, jornalista cuja escrita é sobremaneira engajada com a política nacional. Essas crônicas foram reunidas no livro Pornopolítica: paixões e taras na vida brasileira, do qual extraímos o corpus trazido ao final, em forma de glossário. O corpus em questão se justifica em razão de o próprio ato de escrita consistir numa manifestação de poder. Ressaltam-se a importância da criação lexical, permeada de ideologia, e os aspectos discursivos presentes no texto argumentativo desse cronista. O objetivo último consiste em visualizar, em panorama, a crise nacional na qual estamos imersos, por meio da escolha lexical de um cronista que, hoje, alcança cerca de 50 milhões de brasileiros na mídia, senão com sua escrita, ao menos com sua atuação na mídia televisiva. Trata-se, portanto, de material propício para se traçar um paralelo entre política e linguagem, numa perspectiva discursiva.
\end{abstract}

Palavras-chave: neologismos lexicais, linguagem midiática, estratégias argumentativas, política nacional.

Assim como o stalinismo apagava fotos, reescrevia textos para coonestar seus crimes, o governo do Lula está criando uma língua nova, uma "novi-língua” empobrecedora da ciência política, uma língua esquemática, dualista, nos preparando para o futuro político simplista que está se consolidando no horizonte. Toda a complexidade rica do país será transformada em uma massa de palavras-de-ordem, de preconceitos ideológicos. Lula será eleito por uma oposição mecânica entre ricos e pobres, dividindo o país em "a favor" do povo e "contra", recauchutando significados que não dão mais conta da circularidade do mundo atual. (Grifos ora apostos.) (JABOR, 2006: 186-7)

\section{Primeiras Palavras}

De início, fazemos uma remissão à epígrafe. Trata-se de um fragmento do livro Pornopolítica: paixões e taras na vida brasileira, do jornalista e cronista Arnaldo Jabor. ${ }^{3}$ Nela, algumas temáticas se misturam: política, língua e ideologia. A língua como uma tentativa de entender/explicar a realidade e até mesmo criá-la.

\footnotetext{
* Doutoranda em Língua Portuguesa (UERJ), bolsista CAPES e integrante do GT “Descrição e Ensino de Língua: pressupostos e práticas".

** Pós-Doutor (Universidade do Porto), Professor Adjunto da UERJ, Professor Titular do Instituto Brasileiro de Mercado de Capitais (IBMEC) e Professor Titular das Faculdades Integradas Hélio Alonso.

${ }^{3}$ A partir deste ponto, para evitar repetição, empregaremos AJ para fazer referência a Arnaldo Jabor.
} 
Neste estudo, a proposta é destacar a importância da escolha lexical na produção de um texto e analisar os neologismos ${ }^{4}$ especificamente nas crônicas de Jabor, porque sua escrita é sobremaneira engajada com a política nacional. Optamos por trabalhar, em sua maior parte, com o livro citado porque consiste numa coletânea de crônicas ${ }^{5}$ desse polêmico jornalista. A escolha lexical diz muito de sua obra e visão de mundo. É, portanto, material rico para se traçar uma linha entre política e linguagem verbal, ou melhor, entre política e léxico, como ora se pretende.

Longe de se tratar de uma análise do livro em questão, tem-se por objetivo tão-somente “pinçar” neologismos nele encontrados - aí incluídos alguns estrangeirismos, eis que, como veremos adiante, no curso deste trabalho, deles se socorre o autor para, muitas vezes, expressar a ideologia subjacente, a do americanismo como um mal; em suas palavras, "a América como nosso mito de competência”- e outros recursos lingüísticos, como, por exemplo, os oximoros, bem como examinar a escolha lexical empreendida, e situá-la à luz discursiva.

Algumas palavras como lulo-dirceuzismo, neocinismo, pré-valerioduto, ladrões-teflon, ladrões-espada, breubas, cornologia, cornidão, logocêntrico, suicídios-bomba, porno-corrupto, pornopolítica, bunda-rasgada, impicharam, homem-bomba x homem-cool, desalienante, japorongas, entre outras, inclusive locuções do tipo “recrutas do povo”, “exército democrático”, “militantes imaginários”, “democracia burguesa”, “revolução corrupta”, “tirania esclarecida”, “adesão alienada”, estão presentes em sua escrita, servindo de material para nossa análise.

E esse corpus ora em questão - crônicas jornalísticas reunidas em um livro - se justifica em razão de o próprio ato de escrita ser uma manifestação de poder, o poder de expressar ideias. ${ }^{6}$ Imagine, então, se a esse poder se alia a criação de novas palavras, por um enunciador “ousado” que parece não temer expressar essas ideias e transitar pelo léxico com desenvoltura! Ademais, o corpus jornalístico - não se deve perder de vista que o livro em questão é uma reunião de crônicas jornalísticas publicadas - consiste num veículo que aborda assuntos diversos, guarda relação com a cotidianidade, atinge um grande número de receptores e, segundo André Valente, implica “um padrão médio de linguagem da nossa sociedade". 7

\footnotetext{
${ }^{4}$ Os dicionários utilizados como parâmetro para a consideração do que é ou não neologismo, ou seja, nosso corpora de exclusão, foram o Dicionário Houaiss da Língua Portuguesa e o Dicionário Aurélio Século XXI. Também nos serviu de referência o Vocabulário Ortográfico da Língua Portuguesa (VOLP), edição 2009, de acordo com a Reforma Ortográfica.

${ }^{5}$ Estamos tratando de jornalismo opinativo no gênero "crônica".

${ }^{6}$ Segundo Teun van Dijk, "quanto menos poderosa for uma pessoa, menor o seu acesso às várias formas de escrita e fala. No fim das contas, os sem-poder 'não têm nada para dizer', literalmente, não têm com quem falar ou precisam ficar em silêncio quando pessoas mais poderosas falam, como no caso das crianças, dos prisioneiros, dos réus e (em algumas culturas, incluindo algumas vezes a nossa) das mulheres”. (DIJK, T. Discurso e poder. São Paulo: Contexto, 2008. p. 44).

${ }^{7}$ VALENTE, A. "Produtividade lexical: criações neológicas”. In: PAULIUKONIS e GAVAZZI (orgs.). Da língua ao discurso. Rio de Janeiro: Lucerna, 2005. p. 129.
} 
A semântica também é foco deste estudo, pois, como afirma Jabor na epígrafe que abre este trabalho e no seguinte fragmento: “Com a esquerda no poder, surgiram os ladrões ideológicos: 'Não é roubo, não...', afirmam. 'Trata-se de ‘desapropriação’ dos burgueses que exploram o povo.’” Há, portanto, uma manipulação para atenuar o verdadeiro significado oculto em atos socialmente condenáveis, um verdadeiro desvio de significado e até mesmo uma escolha lexical que tem como propósito “mascarar” ou, por que não dizer, "maquiar” a situação em que vivemos. ${ }^{8}$ Afinal, como ele mesmo nos diz: “A crise nos inclui na política. Aliás, crise no Brasil é quando a política fica visível para a população”.

Este, portanto, o objetivo final do presente artigo: visualizar um pouco da crise nacional na qual estamos imersos por meio da criação/escolha lexical de um cronista que, hoje, alcança cerca de 50 milhões de brasileiros, senão com sua escrita, ao menos com sua atuação na mídia televisiva, pois, se podemos escolher o que lemos, nem sempre podemos escolher o que vemos, pois a televisão “invade” nossa vida.

Desse modo, como nosso “tema maior” - se é que assim podemos chamá-lo - é o léxico, trazemos alguns conceitos teóricos pertinentes à importância da escolha lexical. Logo em seguida, a questão discursiva, na qual o léxico se insere, pois não há como desvincular o vocábulo do contexto. ${ }^{9}$ Por último, alinhamos os neologismos contextualizados.

\section{Importância da Criação/Escolha lexical}

Aqueles macacos que, na Idade do Gelo, se esconderam numas cavernas sujas pra não morrer de frio tiveram de inventar a tal da 'linguagem' para preencher o vazio entre eles e a natureza... (JABOR, 2006: 171)

Não se pode negar que as mudanças sociais estão profundamente associadas à criação lexical, o que, logicamente, motiva relações interdisciplinares. A palavra é um instrumento de manipulação e nenhuma escolha lexical é gratuita.

A língua, segundo senso comum, serve para nos comunicarmos uns com os outros sobre o que nos cerca - os objetos, as pessoas, as ideias etc. e também as respectivas relações existentes. Para tanto, é preciso que recorramos às palavras e que elas expressem as características desses objetos - se reais ou imaginários, se concretos ou abstratos, se naturais ou artificiais.

Segundo Margarida Basílio, “o léxico é um banco de dados previamente classificados, um depósito de elementos de designação, o qual fornece unidades básicas para a construção dos

\footnotetext{
${ }^{8}$ O Prof. Helênio Fonseca de Oliveira, em seu artigo "Conflito entre a natureza pejorativa ou meliorativa das escolhas lexicais e a orientação argumentativa do texto”, examina a natureza desse fenômeno linguístico.

${ }^{9}$ Contextualizar neologismos, segundo Maria Aparecida Barbosa, significa verificar "quem criou a nova palavra, em que universo do discurso foi produzida, em que tempo, em que lugar geográfico e semântico surgiu, para quem foi criada, como foi criada” (“Da neologia à neologia na literatura”. In: OLIVEIRA e ISQUERDO [orgs.], 2001: 35).
} 
enunciados” (BASÍLIO, 2005: 9)..E acrescenta: “O léxico, portanto, categoriza as coisas sobre as quais queremos nos comunicar, fornecendo unidades de designação, as palavras, que utilizamos na construção dos enunciados” (BASÌLIO, 2005: 9).

Assim, o léxico seria a reunião ou o conjunto dessas palavras que utilizamos para expressar nossas necessidades, nosso dia-a-dia, nossas relações. Elas repousariam, portanto, no dicionário nosso acervo lexical real. Mas como explicar aquelas novas palavras que ainda não estão dicionarizadas? Não estariam, elas também, incorporadas ao nosso léxico?

A mesma Margarida Basílio nos apresenta a solução, trazendo a noção de léxico externo (ou real) e léxico mental (ou virtual). Ao primeiro, destinamos as palavras já consagradas pelo uso e já incorporadas aos dicionários; aos segundos, a potencialidade na criação de novas palavras, ou seja, a um sistema preexistente - uma série de entradas lexicais - que permite ao usuário criar novas palavras. Isto porque, como ela explica, a língua obedece a um princípio de economicidade. Não haveria como um falante “decorar” ou memorizar várias palavras a cada nova situação surgida.10

Margarida Basílio ainda afirma que “o léxico é ecologicamente correto”, fazendo o que ela chama de “reciclagem”, ou seja, aproveitando palavras já existentes, ou melhor, pedaços de palavras, para formar outras. Nesse sentido, o processo de formação de palavras utiliza material lingüístico preexistente na língua. Temos, portanto, os neologismos, ou seja, as novas palavras, criadas para dar conta de novas situações, novos conceitos, fatos, objetos, assim designadas por um determinado tempo.

Neste estudo, abordamos prioritariamente - mas não exclusivamente -os neologismos lexicais da categoria "literários” em crônicas de AJ.11 Sobre o tema, Michel Rifaterre diz:

O neologismo literário difere profundamente do neologismo na língua. Este é forjado para exprimir um referente ou um significado novo; seu emprego depende, portanto, de uma relação entre palavras e coisas, em suma, de fatores não lingüísticos; é, antes de mais nada, portador de uma significação, e não é necessariamente captado como forma insólita. O neologismo literário, ao contrário, é sempre captado como uma anomalia e utilizado em virtude dessa anomalia, às vezes até independentemente de seu sentido. Ele não pode deixar de chamar a atenção porque é captado em contraste com seu contexto e porque seu emprego, assim como seu efeito, dependem de relações que se situam inteiramente na linguagem. (Grifos ora apostos.) (Rifaterre Apud VALENTE, 1989 In AZEREDO, 2000)

E acrescenta, para melhor entendimento do uso desse tipo de neologismo:

\footnotetext{
10 Margarida Basílio ilustra essa dificuldade fazendo uma analogia com uma lista telefônica. Se não houvesse esse sistema na língua, teríamos de memorizar as palavras tal como fazemos com números de telefone existentes em uma lista - não há uma regra, uma previsibilidade.

${ }^{11}$ Em crônica recentíssima, datada de 9 de dezembro de 2008, publicada no jornal O Globo, AJ justifica a intensa produtividade lexical da atualidade: "Além da crise econômica e social, vivemos hoje também uma crise lingüística. Sim, os fatos estão superando as interpretações. O mundo aboliu certezas. E palavras novas gemem por existir.”
} 
Quer se trate de uma nova palavra, quer de um sentido novo, ou de uma transferência de categoria gramatical, o neologismo literário suspende o automatismo perceptivo, obriga o leitor a tomar consciência da forma de mensagem que está decifrando, tomada de consciência que é própria da comunicação literária. [...] E só se pode analisá-la descrevendo o funcionamento do neologismo no sistema que constitui o texto. Ele se integra a esse sistema de significações e formas. [...] Sua própria singularidade não se deve ao seu isolamento, mas, ao contrário, ao rigor das seqüências semânticas e morfológicas das quais ele é o ponto de chegada ou de interferência (Rifaterre Apud Valente In: VALENTE, 2007: 25).

Assim é que AJ, quando cria os vocábulos aqui referidos, não se funda propriamente nas necessidades do dia-a-dia, mas sim num contexto intratextual, em que a criação se circunscreve às exigências de sua expressividade no texto. É claro que ele recorre a neologismos de língua, ou culturais, alguns, inclusive, recém-consagrados, como, por exemplo, mensalão, pré-valerioduto etc. Mas, quando ele cria porno-corrupto, homem-cool, pornopolítica, ladrões-teflon, etc., são usos que estão adstritos ao texto e que nele devem ser compreendidos - num sentido microdiscursivo, é claro, porque, num sentido macrodiscursivo, eles devem ser vistos à luz da realidade em que foram criados, levando em conta, como adverte Maria Aparecida Barbosa, o enunciador, o momento de criação, o lugar em que foi criado, dentre outros fatores relevantes.

Essas novas palavras - os significantes, pelo processo de neologia lexical, pois, se fosse a aquisição de significados, estaríamos no campo da neologia semântica - são criadas por derivação e composição. No primeiro caso, apõem-se principalmente os sufixos, que são de grande produtividade lexical. Segundo Mattoso Câmara,

a exploração do valor estilístico dos sufixos é bem apreensível na oratória política, no jornalismo cotidiano e na gíria lato sensu. Uma curiosa conseqüência é a cunhagem de novas palavras de força expressiva. Encontramo-la na linguagem literária e na linguagem popular. (CAMARA: 62)

Nas crônicas em questão, encontram-se neologismos como neocinismo, cornologia, cornidão, entre outros, todos eles em tom jocoso. Sobre o tema, Marcel Cressot observa:

o neologismo, pelo menos na escrita artística, visa igualmente, por substituição do sufixo, uma adequação do volume ou da ressonância da palavra à ideia. Substituem-se sufixos insuficientemente expressivos, reduzem-se e alongam-se massas; uma nova forma de superlativo é representada pelo prefixo 'super' [...] são expressões freqüentes na linguagem jornalística, precisamente com o objetivo de chamar a atenção ou suscitar admiração; há por vezes neologismos jocosos (chauvinite, heroíte), provando, mais uma vez, que nem todos os sufixos são elementos puramente gramaticais. [...] É conveniente, aliás, tomar em consideração a psicologia do neologismo, o desejo que o utente tem desse neologismo. (Grifos ora apostos.) (CRESSOT, 1947: 79)

Como exemplos do processo de composição, temos: porno-corrupto, homem-cool, pornopolítica, ladrões-teflon, entre outros. 
Todos, porém, como se encontra na citação de Rifaterre, provocam uma espécie de “estranhamento” no leitor e clamam por sua participação para decifrar o verdadeiro sentido do termo, por uma "tomada de consciência".

Ainda no campo da escolha lexical, registra-se um recurso utilizado por $\mathbf{A J}$ em suas crônicas para causar impacto no leitor: o coloquialmente conhecido "palavrão", ou termo com significado erótico ou obsceno. Senão, vejamos nas seguintes passagens:

Eta garoto bão, espertalhaço!, ou seja, se diante de si e do mundo, puderes enfunar a barrigona cheia de merda e dizer: 'Sou ladrão sim, mas quem não é? (JABOR: 13)

Em Celebridade, reparem que os bonzinhos têm até uma certa inatualidade careta. Quem nos fascina são os filhos-da-puta... Por quê? Bem, porque os psicopatas são nosso futuro. Eles encarnam a vida moderna, cada vez mais, pois estamos sendo pautados pela luta absurda de dois psicóticos: Osama de um lado, com seu exército de fanáticos rezando com o rabo para Deus, e, do outro, a mesma coisa com Bush e seus malucos. Nossa esperança com os EUA virou pó. (JABOR: 87)

De certa forma, a trepada é a tentativa de encaixe que não acontece nunca, mesmo quando dá certo.(JABOR: 21)

AJ sente-se muito à vontade com esse recurso ao longo do texto e, do ponto de vista dos efeitos causados, sem dúvida remete a certa "intimidade" que ensaia com o receptor, como se estivesse travando um diálogo no "boteco da esquina”, com a liberdade natural, ou melhor dizendo, com a falta de "freios" naturalmente impostos na linguagem escrita, que, via de regra, exige maior elaboração. O processo enunciativo de AJ, assim, pela escolha lexical, aproxima a ambos enunciador e receptor.

Igualmente a utilização frequente de oximoros no texto revela os paradoxos com que o autor se depara em seu cotidiano e que transmite em seu discurso. O oximoro é uma figura que consiste na reunião de palavras contraditórias, um paradoxismo, formando um terceiro conceito que depende da interpretação do leitor. Como o oximoro normalmente soa absurdo, em um primeiro momento, à interpretação do receptor, ele se vê forçado a buscar um sentido metafórico e, acima de tudo, entendê-lo dentro de um contexto macroestrutural. Exemplos no texto:

Procuro com os olhos os bravos soldados do 'exército democrático'. (JABOR: 28)

[...] e tudo teria de ser sob a batuta quase de uma 'tirania esclarecida', que pulasse por cima da paralisia burocrática secular, que passasse por cima do Legislativo cúmplice... (JABOR: 44)

Jeff é o anti-herói heróico. Jeff conhece a boca do boi, a baba das coisas, a barra-pesada. (JABOR: 60)

[o papa] Visitou o Chile de Pinochet e o Iraque de Saddam e, ao contrário de ser uma 'adesão alienada', foi uma crítica muito mais alta, mostrando-se acima de sórdidas políticas seculares... (JABOR: 70)

A bomba americana foi uma 'vitória da ciência'. Hiroshima e Nagasaki dão início à 'guerra limpa', do alto, prefigurando Guerra do Golfo, Afeganistão e Iraque II. (JABOR: 109)

Com Hiroshima, inaugurou-se a 'guerra preventiva' de hoje. (JABOR: 112)

Como em seu neto Nelson Rodrigues, há nele uma 'superficialidade profunda', muito atual neste tempo em que os valores idealizados caíram no chão. (JABOR: 202) 
Em texto recentíssimo, $\mathbf{A J}$ explica a utilização recorrente dos oximoros:

Temos de recorrer aos chamados 'oximoros'. Sabem o que são? O oximoro é a figura retórica mais útil no mundo atual. Nascem de duas palavras contraditórias que se unem para chegar a um terceiro sentido. São como bichos de duas cabeças, centauros da sintaxe, para dar conta da ambivalência do mundo. [...] Podemos falar de um 'silêncio eloqüente' ou o contrário, 'uma eloqüência muda', como tantos discursos com que o governo atual nos afoga.

No texto de AJ, encontramos, também com relativa frequência, estrangeirismos, que consistem num tipo de neologia por empréstimo ou, como ensina André Valente,

em uma transferência lexical para uma nova língua de um elemento já formado pertencente a uma língua estrangeira viva (inglês, russo, alemão etc.) ou morta (latim, grego, sânscrito etc.). Chama-se, às vezes, este tipo de neologia de neologia externa. 'A neologia de empréstimo consiste não na criação do signo, mas na sua adoção’ (Louis Gilbert, La créativité lexicale). (VALENTE, 2007: 24)

Frise-se que, na prática, é comum constatarmos o uso de estrangeirismos como um recurso de prestígio. Assim é que, por exemplo, no cotidiano, temos sale no lugar de liquidação; na Barra da Tijuca, na cidade do Rio de Janeiro, “New York City Center” para nomear um centro que reúne lojas comerciais e cinemas; e por aí vai.

Nos textos de AJ, porém, embora não seja raro notar o uso de estrangeirismos com certa recorrência, nós o vemos quase sempre em tom irônico, ${ }^{12}$ como um recurso para expressar sua ideia de “desprestígio" ao americanismo. Assim, temos: summer-jacket e café society (em "Carnaval é uma promessa de amor”); conference calls e superstars (“Estamos todos no inferno”); early nothing e snuff movie ("Viagem ao pornocinema”); suspension of disbelief ("Finalmente veremos a cara suja do Brasil”); happy end (“A noite em que comentei o Oscar”); bullshit costumeiro e gay power (“Brokeback é um filme sobre machos”); silent generation (“A América pode voltar aos anos 50”); morte on delivery, fast, clean ("Hiroshima: a guerra do século XXI”); nightclub e target 13 ("O lobo com suas grandes asas"); crash, real politik e shit politics ("Viva a catástrofe! Os bons tempos voltaram!”).

Está claro que se trata de um enunciador muito crítico, que produz seus textos impregnados de apelo e afetividade, e que constantemente ironiza ${ }^{14}$ e contrapõe as culturas norte-americana e

\footnotetext{
12 Sobre a ironia, lembramos as palavras de Nilce Sant’Anna Martins: “A ironia, o paradoxo [...] só são apreendidos pelo receptor se ele atenta para a violação da relação de verdade entre o que o emissor diz literalmente e aquilo de que ele fala. O conhecimento do referente é indispensável para que se compreenda o sentido que se deve atribuir ao enunciado. Na ironia, o sentido oposto ao literal. [...] MARTINS, Nilce Sant’Anna. Introdução à estilística. São Paulo: T. A. Queiroz, Editor, 2000.

13 "Era uma meta que ele traçava como um target."

${ }^{14}$ Beth Brait, em seu livro A ironia em perspectiva polifônica, observa: "Necessariamente, e aceitando-se que texto e discurso são processos que implicam produção e recepção, ou seja, sujeitos envolvidos em uma interação, a perspectiva interessa-se também pelo destinatário, que, assim como seu parceiro, detém diferentes papéis, aparecendo como receptor, interlocutor, ouvinte, enunciatário, leitor, e cuja função ativa no discurso será participar da dimensão significativa, na medida em que é o ponto visado pelas estratégias elaboradas pelo produtor.” (p. 14)
} 
brasileira, e até mesmo o que ele chama de "mito da competência da América”. Sobre o tema, esclarece Mattoso Câmara:

É igualmente a tonalidade afetiva que torna, às vezes, tão atraente para o sujeito falante ou o escritor o emprego de um estrangeirismo em que há, por motivos vários, certa vibração emocional. O critério gramatical de só usar um termo estrangeiro quando falta um vernáculo com a mesma exata acepção é inoperante do ponto de vista estilístico.

É inútil, por exemplo, reclamar contra o emprego de big no estilo dos nossos anúncios comerciais. A palavra traz em si aquela sensação da grandeza material que adere à nossa concepção das coisas norte-americanas, e o comerciante experimentado bem sabe que o apelo por meio dela tocará mais fundo na alma do público. (Grifos ora apostos.)

Assim é que constatamos um uso estritamente intencional, com intensa carga irônica e negativa, como nos trechos a seguir transcritos:

A mão displicente do Maurício Marinho pega os três mil reais que surgem no canto do quadro e ele os embolsa, deixando-a escorregar para dentro do paletó, com a calma de quem recebe um troco de cafezinho, e o espetáculo shakesperiano de Jefferson na Câmara, com sua camisa lilás de candomblé, tão Brasil, tão nosso, sua impecável ausência de suor, seu rosto frio, seus biquinhos, suas mãos ondulantes, suas pausas dramáticas... ahhh... suas pausas que poucos atores ousariam, longas, criando a suspension of disbelief, a expectativa, culminando em dedos espetados, sorrisos sardônicos. (JABOR: 83-4)

Tudo bem que são contra a homofobia e todo o bullshit costumeiro. (JABOR: 95)

Auschwitz e Treblinka ainda eram 'fornos' da Revolução Industrial, mas Hiroshima inaugura a guerra tecnológica, virtual, asséptica. A extinção em massa dos japoneses no furacão de fogo fez em um minuto o trabalho de meses e meses do nazismo. O que mais impressiona em Hiroshima é a eficiência, sem trens de gado humano, a morte on delivery, fast, clean, anglo-saxônica. A bomba americana foi uma 'vitória da ciência' (JABOR: 109)

A real politik virou 'shit politics' (JABOR: 207) (Todos os grifos são meus.)

Eles se amontoavam no fundo dos ônibus, em pé, bebiam em bebedouros estragados para colored, moravam num bairrozinho sujo, perto do braço-do-mar onde os barcos pesqueiros de camarão fediam. (JABOR: 104)

Fico chocado e apavorado, pois a América pode voltar ao tempo das 'platitudes' e da silent generation, como na época de miss Alden e do meu dentista de olhos amarelos. (JABOR: 107)

Ser desumano é in. (JABOR: 191)

Observe-se, portanto, que, no terceiro fragmento, quando AJ se refere à morte, recorre a termos da língua inglesa, como se houvesse tamanha identificação ou colagem entre o substantivo morte e a respectiva adjetivação - on delivery, fast, clean - que não fosse possível usar a língua portuguesa. Temos, pois, um efeito estilístico muito mais intenso.

\section{Escolha Lexical e Questão Discursiva no Texto Argumentativo de AJ}

mas até os xingamentos eram previstos na cartilha marxista: acusávamo-nos de 'hesitantes' ou 'radicais' ou 'sectários' ou 'pequeno-burgueses' ou 'alienados' ou 'provocadores' ou 'obreiristas' ou 'aventureiros' ou 'liberais' ou o diabo a quatro. E eu, do meu canto 
neurótico, pensava: 'Não ocorre a ninguém que há também os invejosos, os ignorantes, os mentirosos, os paranóicos, os babacas e os FDPs? (JABOR: 213)

O objetivo de toda argumentação, como dissemos, é provocar ou aumentar a adesão dos espíritos às teses que se apresentam a seu assentimento: uma argumentação eficaz é a que consegue aumentar essa intensidade de adesão, de forma que se desencadeie nos ouvintes a ação pretendida (ação positiva ou abstenção) ou, pelo menos, crie neles uma disposição para a ação, que se manifestará no momento oportuno. (PERELMAN; OLBRECTHS-TYTECA, 2002: 50)

O desenvolvimento que se estende na multiplicidade discursiva não é só o desenvolvimento dos conceitos, mas atinge igualmente o elemento da linguagem. É a multiplicidade das designações possíveis - segundo a diversidade das línguas - o que concede maior potência à diferenciação conceitual. (GADAMER, 2004: 561)

Não há dúvida de que toda palavra ou locução empregada num texto deve ser examinada no contexto e de que a escolha lexical define seu rumo. Até então, nada mais do que o óbvio. Como lembra Maria Aparecida Baccega,

[a palavra] 'canta' sempre num salão de baile, onde ‘dança conforme a música', utiliza-se de máscaras ou despe-se, permitindo que se veja toda sua beleza. OU seja: a palavra nunca está só - ela sempre aparece acompanhada. Ela está sempre num discurso, ou seja, é no discurso, que Pêcheux denomina de formação discursiva, que a palavra assume seu significado. E os discursos nos quais ela aparece são aqueles que a própria língua permite.

Exemplo claro disso é o emprego de "consciências virginais” por AJ. Sem uma visão do contexto intra e extradiscursivo, muito se perde de seu sentido.

Trata-se, de fato, da crônica "Maldita seja a pornopolítica", em que AJ está maldizendo os políticos. A expressão está inserida no seguinte parágrafo:

Malditas sejam também as 'consciências virginais', as mentes 'puras' que se escandalizam com os horrores, mas nada fazem; malditos os alienados e covardes, malditos os limpos, os não-culpados, os indiferentes, que se acham superiores aos que sofrem e pecam; malditos intelectuais silenciosos que ficam agarrados em seus dogmas e que preparam a espúria reeleição dessa gente e a chegada posterior dos populistas e falsos evangélicos mais sórdidos do país! (JABOR: 229)

Transcrito o parágrafo e estabelecidas as conexões com nosso "conhecimento de mundo", fica claro que ele se refere ao episódio do mensalão e ao alegado desconhecimento dos fatos envolvidos no escândalo pelo presidente Lula.

Ora, nitidamente, em todos os textos observados, dentro do contrato de comunicação midiático, AJ busca persuadir e seduzir o leitor, com ênfase para a sedução, tendo em vista o amplo apelo à emotividade do leitor. ${ }^{15} \mathrm{E}$, quando se fala em persuasão e sedução, remete-se a Patrícia Ferreira Neves Ribeiro, que assim resume:

\footnotetext{
${ }^{15}$ Como exemplo, veja-se a seguinte passagem na crônica "Maldita seja a pornopolítica”: "Malditos anos de cara suja, malditos olhinhos vorazes, malditos espertos fugitivos da cassação; anematizados e desgraçados sejam os que levam dólares na cueca e, mais que eles, os que levam dólares às Bahamas, malditos os que usam o ‘amor ao povo’ para
} 
Tanto persuadir como seduzir têm em comum o controle do outro. No entanto, na persuasão esse controle relaciona-se à razão e, na sedução, à emoção. O princípio da persuasão fundamenta-se no ato de fazer o outro crer em algo, por meio de um rigor lógico, com vistas à sua adesão. Já o princípio da sedução é o de dar prazer ao outro, ou seja, o de levá-lo a experimentar estados emocionais agradáveis que provoquem alterações em seu comportamento. (RIBEIRO, 2003: 122)

AJ traz o leitor para seu universo do discurso, para a sua forma de pensar, senão para fazê-lo concordar com seus argumentos, ao menos para conclamá-lo a deles discordar com contraargumentos à mesma altura. Ou seja, ele exige do leitor um posicionamento ideológico - e, para tanto, recorre a um léxico que poderia ser chamado de “contundente” (essa é sua escolha). Não há meias palavras, não há sentidos ocultos, as palavras são proferidas “nua e cruamente”, para causar impacto, para fazer com que o leitor compartilhe determinadas opiniões. Ainda sobre o tema, Ingedore Koch sustenta que

o ato de argumentar, isto é, de orientar o discurso no sentido de determinadas conclusões, constitui o ato lingüístico fundamental, pois a todo e qualquer discurso subjaz uma ideologia, na acepção mais ampla do termo. A neutralidade é apenas um mito: o discurso que se pretende 'neutro', ingênuo, contém também uma ideologia - a de sua própria objetividade. (KOCH, 2006: 17)

Em AJ, não há ocultamento nem tentativa de mostrar-se neutro. Muito pelo contrário. A escolha lexical é bastante clara em demonstrar seu posicionamento. Vejamos:

Nunca achei o Dirceu ladrão, apesar de ele não acreditar. Defendi-o até no caso Waldomiro Diniz, achando que ele tinha sido apenas tolerante com um sem-vergonha 'útil'. Depois é que percebi a extensão de seu plano 'revolucionário'. E ataquei-o, porque ele, do passado em preto e branco, queria invadir o presente, com uma subversão regressista que nos jogaria de volta a um tempo morto. [...] Ataquei o Dirceu por seu 'aventureirismo', 'voluntarismo' e 'desvio de esquerda' (para usar a linguagem do PT). Muita gente boa ainda acha que 'sempre foi assim', que Dirceu mereceu a cassação por 'corrupção'. Mas, antes, nunca houve uma tentativa de se 'tomar o Estado' usando o dinheiro público pelo 'bem do povo'. Dirceu caiu por mais uma falha de nossa esquerda de trapalhões, como em 63 ou em 68, no Congresso de Ibiúna. (Grifos ora apostos.) (JABOR: 156)

Observem-se os termos em negrito. Não se pode atribuir a escolha a um mero ato nãointencional. Inevitável lembrarmo-nos das palavras de Ingedore Koch:

Ao produzir um discurso, o homem se apropria da língua, não só com o fim de veicular mensagens, mas, principalmente, com o objetivo de atuar, de interagir socialmente, instituindo-se como EU e constituindo, ao mesmo tempo, como interlocutor, o outro, que é, por sua vez, constitutivo do próprio EU, por meio do jogo de representações e de imagens recíprocas que entre eles se estabelecem. (KOCH, 2006: 19)

justificar suas ambições fracassadas, malditos severinos que rondam ainda, malditos waldomiros e waldemares que rondam ainda, malditos dirceus, arroz-de-festa de intelectuais mal-informados (ic), malditos sejam, pois neles há o desejo de fazer regredir o Brasil para o velho Atraso pustulento, em nome de suas doenças mentais infantis!” (JABOR: 230). 


\section{A Questão da Ideologia}

A linguagem humana é nosso instrumental número 1 em comunicação. Nesse passo, uma língua está a serviço de determinada comunidade e dispõe de um mecanismo que propicia a construção de palavras novas, para atender às necessidades do progresso material e intelectual. As línguas se modificam no tempo, no espaço geográfico, entre as classes sociais. Com a língua, movimentam-se o espírito e o intelecto do homem. E, como nos diz José Luiz Fiorin (2005: 16), “é no nível do discurso que devemos, pois, estudar as coerções sociais que determinam a linguagem”.

As línguas humanas mudam, portanto, porque não consistem em realidades estáticas. Essas mudanças - em estruturas e palavras que existiam e deixam de existir ou a sua ocorrência modificada em sua forma, função ou significado - se dão de forma lenta e gradual e não nos damos conta delas - nossa sensação repousa na permanência, e não na dinamicidade.

Podemos concluir que, dado o nosso recorte, também ele está impregnado da visão de AJ sobre a sociedade. Não nos esqueçamos de que, para Bakhtin (2004: 15), "todo signo é ideológico; a ideologia é um reflexo das estruturas sociais; assim, toda modificação da ideologia encadeia uma modificação da língua” (grifo meu). Exemplos no texto:

O que apavora é que quase expulsaram Clinton por sexo e, hoje, ninguém falou em impeachment para Bush, um canalha que destruiu o nome da América, dividiu o Ocidente e criou possibilidades reais de guerra nuclear para os fanáticos. (JABOR: 16-7)

A religião não é o ópio do povo; é a bomba do povo. (JABOR: 16-7)

\section{Os Neologismos Contextualizados (Glossário)}

O presente corpus contém 41 neologismos, selecionados pelo critério da expressividade critério intrinsecamente subjetivo. Optou-se prioritariamente pela inclusão no corpus de neologias lexicais. Todos os verbetes são organizados na ordem de surgimento nas crônicas e contêm o respectivo contexto (transcrição do trecho ou frase em que aparece, de modo a guardar unidade de significação).

Os verbetes identificam os termos neológicos em grifo.

1) Verbete: apaga-a-luz (p. 12)

Contexto: "se, no fundo do coração, achas que roubar o Estado ou os estados ou as prefeituras ou os camelôs ou os lixeiros ou os mendigos é, portanto, uma causa nobre e um ato quase revolucionário, que a mutreta, a maracutaia, a 'mão grande', o apaga-a-luz, o 'me da o meu aí' têm algo de transgressão pós-moderna, algo de Robin Hood para si mesmo, como dizes, soltando a piada 'ah-ah, roubo dos ricos para o pobre aqui... ah-ah.” 
2) Verbete: impicharam (p. 16)

Contexto: "Foi feio ver o Clinton jurar em close na TV que jamais comera a moça e, dias depois, o espermatozóide guardado por Linda Tripp vir a público para destruí-lo. Quase impicharam o homem, e, como a besta careta do Al Gore ficou com medo de defender Clinton na campanha, pois sua mulher e a América podiam considerá-lo conivente com a sacanagem, Bush foi eleito, com a fraude do irmãozinho na Flórida.”

3) Verbete: carmens (p. 21)

Contexto: "Outras mulheres me fascinaram pela impossibilidade de atingi-las, as carmens pareciam minha mãe perdida, e fiquei atraído pelo charme infinito das histéricas.”

4) Verbete: meninas-modelos (p. 24)

Contexto: "E Daniella era branca e bela demais, frágil, dama do círculo dos rapazes 'finos' de São Paulo, o clube dos sedutores milionários que freqüentam em revezamento as meninas-modelos.”

5) Verbete: pegadinhas (p. 26)

Contexto: “E a festa era tão pretensiosa que os ricos 'finos’ começaram a sabotá-la. Penetras se organizam em pegadinhas e muitos penetraram não indo.”

6) Verbete: bunda-rasgada (p. 30)

Contexto: "Meu Deus... eu que imaginava os grandes festivais do socialismo com Lenin e Fidel, eu que era um herói virei um bunda-rasgada!”

Comentário: Alusão ao vocábulo bunda-mole, mais usual.

7) Verbete: frase-provocação (p. 34)

Contexto: “Anos depois me lembraria dela, quando li a frase-provocação de Nelson Rodrigues: ‘A pior forma de solidão é a companhia de um paulista...”

8) Verbete: tucanos (p. 38)

Contexto: "Escrever o que sobre essa paralisia histórica mundial que finge ser dinâmica, mas apenas roda no mesmo erro, como um aleijado caído no chão, girando em volta de si mesmo, entre Bush e Osama, entre Lula e tucanos, entre Garotinhos, Rosinhas, irrelevâncias políticas regressistas?"

Comentário: Neologia semântica, remetendo aos indivíduos filiados ao Partido Político PSDB.

9) Verbetes: Garotinhos e Rosinhas (p. 38)

Contexto: "Escrever o que sobre essa paralisia histórica mundial que finge ser dinâmica, mas apenas roda no mesmo erro, como um aleijado caído no chão, girando em volta de si mesmo, entre Bush e Osama, entre Lula e tucanos, entre Garotinhos, Rosinhas, irrelevâncias políticas regressistas?" 
10) Verbete: homens-bomba (p. 44)

Contexto: "Vocês é que têm medo de morrer, eu não. Aliás, aqui na cadeia vocês não podem entrar e me matar... mas eu posso mandar matar vocês lá fora... Nós somos homens-bomba. Na favela tem 100 mil homens-bomba... Estamos no centro do Insolúvel, mesmo... Vocês no bem e eu no mal e, no meio, a fronteira da morte, a única fronteira.”

11) Verbete: microondas (p. 45)

Contexto: "Nós somos uma empresa moderna, rica. Se funcionário vacila, é despedido e jogado no microondas... ha ha... Vocês são o Estado quebrado, dominado por incompetentes.”

Comentário: Neologia semântica, eis que microondas, aqui, não tem o sentido original do termo, mas uma espécie de “aparelho" que os traficantes usam para queimar pessoas que lhes são contrárias ou prejudiciais, uma justiça manu militari, feita com as próprias mãos. Com esse significado, não há registro no corpora de exclusão.

12) Verbete: pornocinema (p. 49)

Contexto: "Viagem ao pornocinema."

13) Verbete: pornô-estrelas (p. 52)

Contexto: “[...] já as pornô-estrelas são muitas...”

14) Verbete: desdramatizada (p. 55)

Contexto: “‘É Godard puro o filme pornô...', me diz, ‘ação desdramatizada, planos saturados... Veja."

15) Verbete: meia-bomba (p. 56)

Contexto: "Na meia-bomba está toda a humanidade."

Comentários: Com sua capacidade realizada pela metade.

16) Verbete: pornopolítica (p. 57)

Contexto: "A saciedade de todos os desejos chama-se morte. Não mais a morte iminente da guerra total, mas a morte inscrita em cada objeto, nesta crueza de fim de história em que vivemos - a pornopolítica."

17) Verbete: porno-corrupto (p. 58)

Contexto: "Come-se o Brasil como se comem as pornoatrizes. Como no filme pornô, não se esconde mais nada. O porno-corrupto de hoje é explícito, se orgulha disso, na política ou na violência.”

Comentários: O uso de “porno” por Jabor serve para mostrar o que os filmes da categoria pornô fazem: mostram tudo. Dessa forma, o pornocorrupto é aquele que não receia mais esconder a prática da corrupção; ela está às claras e existe até prazer em mostrá-la. 
18) Verbete: neoconservadores (p. 69)

Contexto: "Senti que o sonho de entendimento socialismo-capitalismo ia ser apenas o triunfo triste dos neoconservadores."

Comentários: analogia com o termo neoliberalismo; soa como um oxímoro, com o uso do prefixo neo- (novo) combinado ao termo conservador (o que é antigo).

19) Verbete: texto-cabeça (p. 76)

Contexto: "Por isso, neste texto-cabeça, nesta faíscade ferradura que me calça os pés, vejo com esperança e otimismo que muitas novidades que nos parecem detestáveis e prejudiciais podem trazer novas ideias operativas que ajudarão a reformar o país.”

20) Verbete: monolitismo (p. 80)

Contexto: "Hoje, tanto no fanatismo do Oriente quanto no monolitismo da massificação ocidental, vemos esse perigo e desejo.”

Comentários: alusão ao vocábulo monolítico (= diz-se de estrutura em que há uma só massa contínua de material; diz-se do caráter, do sentimento, da crença etc. que não apresenta rupturas, que é íntegro). ${ }^{16}$

21) Verbete: desalienante (p. 93)

Contexto: “Acabou o programa e eu, herói, me ergui, feliz de minha tarefa desalienante. Eu estava vingado."

22) Verbete: autoderrisão (p. 96)

Contexto: "Mais tarde, com o tempo, surgiram as 'bichas loucas', que se assumiam com um toque de autoflagelação, de autoderrisão, caricaturas da mãe odiada e amada...”

23) Verbete: suicídios-bomba (p. 100)

Contexto: "Osama pode tudo, pode planejar o que quiser: cartas com antrax, garrafinhas de gás soltas nas ruas, suicídios-bomba, produtos químicos no metrô.”

24) Verbete: logocêntrico (p. 101)

Contexto: "Osama arrebentou nosso mundo logocêntrico. Nosso projeto foi interrompido pelo 'intempestivo', o que está fora do tempo.”

25) Verbete: japoronga (p. 110)

Contexto: "Na 'luta pela democracia', rasparam da face da terra os japorongas, seres oblíquos que, como dizia Truman em seu diário: 'São animais cruéis, obstinados, traidores.” Seres inferiores de olhinho puxado podiam ser fritos como shiitakes.”

26) Verbete: cornidão (p. 113)

Contexto: “A cornidão é um sentimento nacional.”

${ }^{16}$ Novo Dicionário Aurélio da língua portuguesa. 3 ed. São Paulo: Positivo, 2004, p. 1355. 
27) Verbete: escritores-fantasma (p. 113)

Contexto: "Sou vítima de escritores-fantasmas que se escondem na internet."

28) Verbete: cornologia (p. 114)

Contexto: “Que vou fazer? Sei que a cornologia é uma ciência respeitável. Conheço vários tipos famosos de crifrudos, como o 'corno Papai Noel' - aquele que não vai embora por causa das crianças.”

29) Verbete: mensaleiros (p. 116)

Contexto: "Com os mensaleiros se candidatando de novo, com os sanguessugas impunes, com o PMDB nos Correios, estamos com uma galhada florescente nas cabeças.”

30) Verbete: chefe-suicida (p. 129)

Contexto: "O Muhamad Atta, aquele chefe-suicida, estava deitado numa cama de ouro e rubis, com odaliscas do Catumbi rebolando a dança do ventre...”

31) Verbete: nave-espacial-barraco (p. 137)

Contexto: "E o ônibus parou de rir, o néon se apagou, o halterofilista se amansou e a rua inteira ficou calma, e ele ficou calmo, e pôde sentar no seu canto de calçada, feliz com a salvação da família, e pôde transmitir contente para a nave-espacial-barraco...”

32) Verbete: breubas (p. 140)

Contexto: "Há o ladrão com anel de doutor, conhecedor dos meandros, frestas e breubas dos códigos. Sabe das instâncias infindáveis, sabe dos recursos, agravos, embargos, chicanas. A PF prende e a lei solta.”

Comentários: Referência ao “breu”, à escuridão, existente na legislação brasileira.

33) Verbete: ladrões-espada (p. 141)

Contexto: "Há os ladrões-espada, competentes, estudiosos, olhados com unção nas churrascarias.

‘Aquele lá é gatuno, cara’, diz o executivo. 'É... mas é craque, dá nó em pingo d’água', retruca o outro com admiração.”

34) Verbete: ladrões-teflon (p. 141)

Contexto: "Há os ladrões populistas, políticos que 'amam o povo’ e que conseguem ficar sempre limpinhos. São os ladrões-teflon - nada gruda neles.”

35) Verbete: pré-valerioduto (p. 176)

Contexto: “[...] o honrado Paulo Venceslau, que descobriu o pré-valerioduto há cinco anos em São José do Rio Preto e foi expulso por Lula [...].”

36) Verbete: neocinismo (p. 185)

Contexto: "Este neocinismo está a desmoralizar as palavras, os raciocínios. A cada cassado perdoado, a cada negação do óbvio, a cada testemunha muda, aumenta a sensação de que as ideias 
não correspondem mais aos fatos! Pior: que os fatos não são nada - só valem as versões, as manipulações.”

37) Verbete: lulo-dirceuzismo (p. 186)

Contexto: "No duro, os intelectuais matreiros (onde estão os marxistas de gabinete?) votarão em Lula de novo e dizem que 'sempre foi assim’ porque, no duro, eles acham que o lulo-dirceuzismo estava certo, sim, e que o PT e sua quadrilha fizeram bem em assaltar o Estado para um 'fim revolucionário’. Na moita - porque não se declaram -, não são democratas.”

38) Verbete: papai-reaça (p. 212)

Contexto: "No entanto, como era delicioso sentir-se importante, como era bom conspirar contra tudo, desde o papai-reaça até a invasão do imperialismo ianque.”

39) Verbete: homem-cool (p. 218)

Contexto: “[...] pois Deus já está entre nós armado até os dentes, acaba a fleuma, a displicência debonnaire, o alívio da caridade ou mesmo a deliciosa sensação da canalhice, acaba a coolness, pois o homem-bomba desbancou o homem-cool, ficará mais evidente o desejo brutal do egoístas [...].”

Comentários: Referência a Bush.

40) Verbete: valérios (p. 228)

Contexto: "Malditos sejais, carecas sinistros, valérios sem valor, homúnculos dedicados a se infiltrar nas brechas...”

Comentário: Alusão a Marcos Valério, um dos personagens do escândalo político do valerioduto.

41) Verbete: valerioduto (p. 229)

Contexto: “de onde jorrou o grosso do dinheiro do valerioduto!”

\section{6. Últimas palavras}

Arnaldo Jabor é um autor extremamente produtivo do ponto de vista lexical e oferece manancial para vários estudos nesse campo. Tendo em vista a alta carga argumentativa de seus textos, ele também atende ao segmento que se volta aos estudos discursivos, ao lançar mão, como pudemos constatar, de várias estratégias para despertar a atenção do leitor e conclamá-lo a vivenciar o texto produzido - produção cujo mérito tanto se dirige ao autor (AJ) quanto ao leitor.

\section{Referências}

BAKHTIN, M. Marxismo e filosofia da linguagem. São Paulo: Hucitec, 2004.

BARBOSA, M A. Da neologia à neologia na literatura. In: OLIVEIRA e ISQUERDO (orgs.). 2001. BASÍLIO, M. Formação e classes de palavras no português do Brasil. São Paulo: Contexto, 2005. CÂMARA JR, J. M. Contribuição à estilística portuguesa. 3ed. Rio de Janeiro: Ao Livro Técnico, 1978.

CRESSOT, M. O estilo e as suas técnicas. Lisboa: Edições 70, 1947. 
DIJK, T. Discurso e poder. São Paulo: Contexto, 2008.

GADAMER, H-G. Verdade e método I: traços fundamentais de uma hermenêutica filosófica. Petrópolis: Vozes, 2004.

GOMES, W. Transformações da política na era da comunicação de massa. São Paulo: Paulus, 2004.

FARACO, C A. Lingüística histórica: uma introdução ao estudo da história das línguas. São Paulo: Parábola Editorial, 2005.

FIORIN, J L. Linguagem e ideologia. São Paulo: Ática, 2005.

JABOR, A. Pornopolítica: paixões e taras na vida brasileira. São Paulo: Objetiva, 2006.

KOCH, I G V. Argumentação e linguagem. São Paulo: Cortez, 2006.

OLIVEIRA, H F. Conflito entre a natureza pejorativa ou meliorativa das escolhas lexicais e a orientação argumentativa do texto. Texto apresentado no IX Fórum de Estudos Lingüísticos da UERJ - Mesa-redonda: "Estudos Lexicais: temas e problemas".

PAULIUKONIS, M A L. Ensino do léxico: seleção e adequação ao contexto. In:

GAVAZZI, S (orgs.). Da língua ao discurso: reflexões para o ensino. Rio de Janeiro: Lucerna, 2005.

PERELMAN, C; OLBRECTHS-TYTECA, L. Tratado da argumentação: a nova retórica. São Paulo: Martins Fontes, 2002.

RIBEIRO, P F N R. Estratégias de persuasão e de sedução na mídia impressa. In: PAULIUKONIS, M A L; GAVAZZI, S. Texto e discurso: mídia, literatura e ensino. Rio de Janeiro: Lucerna, 2003.

VALENTE, A. Produtividade lexical: criações neológicas. In: PAULIUKONIS; GAVAZZI (orgs.). Da língua ao discurso. Rio de Janeiro: Lucerna, 2005.

. A produtividade lexical em diferentes linguagens. In: AZEREDO, J C (org.), 2000.

. Neologismos literários em romance de Mia Couto. In: (org.). Língua portuguesa e

identidade: marcas culturais. Rio de Janeiro: Caetés, 2007. 